Information for citation:

Kondratieva K. S., Groysberg A. I. Osobennosti provedeniya protsedury restrukturizatsii zadolzhennosti fizicheskogo litsa $v$ dele o bankrotstve [Restructuring of a Physical Person's Debt in Bankruptcy Case: Features of the Procedure]. Vestnik Permskogo Universiteta. Juridicheskie Nauki - Perm University Herald. Juridical Sciences. 2016. Issue 34. Pp. 418-425. (In Russ.). DOI: 10.17072/1995-4190-2016-34-418-425.

UDC 343.535

DOI: 10.17072/1995-4190-2016-34-418-425

\title{
RESTRUCTURING OF A PHYSICAL PERSON'S DEBT IN BANKRUPTCY CASE: FEATURES OF THE PROCEDURE
}

\author{
K. S. Kondratieva \\ Higher School of Economics (Perm branch) \\ 38, Studencheskaya st., Perm, 614070, Russia \\ ORCID: 0000-0002-3925-5911 \\ ResearcherID: G-8872-2015 \\ Articles in DB «Scopus» / «Web of Science»: \\ DOI: $10.17072 / 1995-4190-2015-4-68-77$ \\ e-mail: kcenua-9@mail.ru
}

\section{A. I. Groysberg}

Higher School of Economics (Perm branch)

38, Studencheskaya st., Perm, 614070, Russia

ORCID: 0000-0001-8041-5369

ResearcherID: M-5851-2015

Articles in DB «Scopus» / «Web of Science»:

DOI: $10.17072 / 1995-4190-2015-4-68-77$

e-mail: anna-groisberg@yandex.ru

Introduction: the article considers features of carrying out a procedure of restructuring a debt of a citizen who is not an individual entrepreneur in bankruptcy case. Purpose: to study the rehabilitation nature of the structuring procedure based on distinguishing its stages. Methods: analytical and system methods, comparative and legal, technical and legal methods are used. Results: legal consequences of introducing the procedure of restructuring a debtor's debt allow him to stabilize his financial position and to save his property to meet creditors' requirements. Actions of a financial manager, first of all, are aimed at providing creditors with a right to take part in the case of the debtor's bankruptcy. In their turn, creditors are recommended to act with due care and discretion to keep an opportunity to participate in settling the debtor's legal destiny. The law has additional provisions protecting rights of creditors of the first and second order, and also creditors' rights referring to the current liabilities, the debt to which shall be repaid before the approval of the debt restructuring plan. Conclusions: having introduced the institute of citizens' debts restructuring, the Russian legislation legally enables debtors to pay debts during a long term and to keep their property at the same time. Giving an opportunity to choose a bankruptcy procedure applied to debtorsconsumers depending on their liabilities, income and size of debts, the legislator purposes to protect the debtor from loss of property and from psychological stress, thereby strengthening social and economic infrastructure.

Keywords: bankruptcy; physical person; debt restructuring; restructuring plan; financial manager

(C) Kondratieva K. S., Groysberg A. I., 2016 


\title{
Information on Russian
}

\section{ОСОБЕННОСТИ ПРОВЕДЕНИЯ ПРОЦЕДУРЫ РЕСТРУКТУРИЗАЦИИ ЗАДОЛЖЕННОСТИ ФИЗИЧЕСКОГО ЛИЦА В ДЕЛЕ О БАНКРОТСТВЕ}

\author{
К. С. Кондратьева \\ 614070, Россия, г. Пермь, ул. Студенческая, 38 \\ ORCID: 0000-0002-3925-5911 \\ ResearcherID: G-8872-2015 \\ Статьи в БД «Scopus» / «Web of Science»: \\ DOI: $10.17072 / 1995-4190-2015-4-68-77$ \\ e-mail: kcenua-9@mail.ru
}

Кандидат юридических наук, доцент кафедры гражданского и предпринимательского права Национальный исследовательский университет «Высшая школа экономики» (Пермь)

\section{А. И. Гройсберг}

Кандидат юридических наук, доцент кафедры гражданского и предпринимательского права Национальный исследовательский университет «Высшая школа экономики» (Пермь)

614070, Россия, г. Пермь, ул. Студенческая, 38

ORCID: 0000-0001-8041-5369

ResearcherID: M-5851-2015

Статьи в БД «Scopus» / «Web of Science»:

DOI: $10.17072 / 1995-4190-2015-4-68-77$

e-mail: anna-groisberg@yandex.ru

Введение: статья посвящена рассмотрению особенностей проведения прочедуры реструктуризации задолженности гражданина, не являющегося индивидуальньм предпринимателем, в деле о банкротстве. Цель: на основе выделения этапов проведения процедуры реструктуризации изучить ее реабилитациионный характер. Методы: использованы аналитический и системный методы, сравнительно-правовой, техникоюридический. Результаты: юридические последствия введения процедуры реструктуризачии задолженности должника позволяют стабилизировать его финансовое положение, обеспечить сохранность имущества должника в ичелях удовлетворения требований кредиторов. Действия финансового управляющего прежде всего направлены на обеспечение права кредиторов принять участие в деле о банкротстве должника. В свою очередь, кредиторам рекомендуется действовать с должной заботливостью и осмотрительностью с тем, чтобы сохранить возможность участвовать в определении правовой судьбы должника. Законом дополнительно защищаются права кредиторов первой и второй очереди, а также права кредиторов по текущим обязательствам, задолженность перед которыми должна быть погашена до утверждения плана реструктуризациии долгов. Выводы: с введением института реструктуризации задолженности гражданина российское законодательство предоставило должникам легальную возможность в течение длительного срока осуществлять погашение имеющихся долгов и одновременно сохранять свое имущество. Законодатель, предоставляя возможность выбора произедуры банкротства, применяемой к должникам-потребителям в зависимости от их обязательств, дохода и размера долгов, ставит ичелью защчитить должника от имущеественного краха, психологического потрясения, тем самым укрепляя социальноэкономическую инфраструктуру.

Ключевые слова: банкротство; физическое лицо; реструктуризация задолженности; план реструктуризации; финансовый управляющий 


\section{Introduction}

Today so-called procedures preventing a debtor from being acknowledged as a bankrupt through legislative debt relief with no full realization of the debtor's property but basically at the expense of future revenue seizure over a certain period of time are becoming more and more popular [1, p. 162].

Rehabilitation as a type of bankruptcy was first introduced in the 1930s but gained popularity only in 1979. At present, the USA has a legal ethical postulate of apparent evidence that each debtor should have an opportunity for a new start, or the so-called "fresh start", after an economical failure [3, p. 549].

The USA law proposes an individual in a financial trouble to set up a debt restructuring plan in order to keep the property (Chapter 13 of the Bankruptcy Code $)^{1}$, which is the most profitable for the debtor according to most private insolvency foreign researchers $[2,3,4,5]$.

In Russia, the norms governing insolvency (bankruptcy) of citizens who are not individual entrepreneurs entered into force on October 1, 2015.

Necessary amendments were made to the Federal Law of October 26, 2002 № 127-FZ “On Insolvency (Bankruptcy)"” (hereinafter - Bankruptcy Law) based on the Federal Law of December 29, 2014 № 476-FZ³.

Resolution № 45 “On certain questions connected with the introduction of procedures applied in cases of insolvency (bankruptcy) of citizens"

${ }^{1}$ U.S. Code: Title 11 - BANKRUPTCY (Current $\square$ through $\square$ 114-93 not 92) // Pub. L. 95-598, title I, $\S 101$, Nov. 6, 1978, 92 Stat. 2549.

${ }^{2}$ On Insolvency (Bankruptcy): the Federal Law of 26.10.2002 No. 127-FZ (as revised 03.07.2016; amendments entered into force 01.09.2016) // Legislation Bulletin of the Russian Federation. 28.10.2002. No. 43. Art. 4190.

${ }^{3}$ On the Amendments to the Federal Law "On Insolvency (Bankruptcy) and Certain Legislative Acts of the Russian Federation Regarding Regulating Rehabilitation Procedures Applied to the Debtor Citizen: the Federal Law of 29.12.2014 No. 476-FZ (as revised by the Federal Law of 29.06.2015 No. 154-FZ) // Legislation Bulletin of the Russian Federation of 05.01.2015 No. 1 (Part I) Art. 29.

${ }^{4}$ On certain Questions Connected with the Introduction of Procedures Applied in Cases of Insolvency (Bankruptcy) of Citizens: Resolution of the Plenum of the $\mathrm{Su}-$ preme Court of the Russian Federation of 13.10.2015 No. 45 // Legislation Bulletin of the Russian Federation. December, 2015, No. 12. (hereinafter - Resolution № 45) of the Plenum of the Supreme Court of the Russian Federation from October 13, 2015 clarifies the abovementioned regulations.

Thus, in accordance with statistics the personal institute is increasingly in demand in Russia.

The highest personal bankruptcy rates since this institute began functioning in 2015 have been reported for June 2016. According to the Unified Federal Register of Bankruptcy Data (hereinafter EFRSB), 1771 decisions on acknowledging citizens as bankrupts were made in May. The number of decisions on the validity of bankruptcy petitions and introduction of debt restructuring has also grown. In June, these figures reached 742, a peak since the beginning of work. Since the beginning of the year, the number of such determinations more than doubled - from 300 in January to 677 and 622 in April and May respectively ${ }^{5}$.

\section{Main Content}

The Russian legislation provides for three procedures that can be applied to the debtor: debt restructuring, assets sale and peace agreement.

Debt restructuring is a rehabilitation procedure allowing a debtor to renegotiate the payment terms. It is similar to the debt regulation plan in the American legislation.

Such a procedure seems to have advantages for both the debtor and the creditor. The debtor has an opportunity to restore his solvency and make gradual debt repayment as well as keep his property while the creditor is legally guaranteed that his claims will be satisfied.

Additionally, establishing the period of the debt restructuring plan fulfillment, Clause 2 of Article 213.14 of the Bankruptcy Law actually allows a debtor payment extension up to three years. In comparison, the period to restore solvency within external management procedure for legal entities does not exceed two years (Clause 2 of Article 93 of the Bankruptcy Law).

It is proposed to study the rehabilitation nature of the debtor's solvency restoration and debt restructuring plan fulfillment based on distinguishing the stages of this procedure.

\footnotetext{
${ }^{5}$ Unified Federal Register of Bankruptcy Data. URL: http://bankrot.fedresurs.ru/NewsCard.aspx?ID=772 (accessed 20.09.2016).
} 


\section{The Main Stages of the Procedure for Restructuring of a Citizen's Debt}

It is possible to distinguish the following main stages of the procedure for restructuring of a citizen's debt:

- court order to introduce a debt restructuring plan;

- publication of information about the validity of the bankruptcy petition and initiation of debt restructuring;

- sending notifications of the initiation of the debt restructuring procedure;

- drafting a debt restructuring plan and sending it to the interested parties;

- approval of the plan at the first meeting of creditors;

- court approval of the debt restructuring plan;

- plan fulfillment;

- preparing a report and termination of debt restructuring.

We propose to consider each of the stages in more detail.

\section{The Decision to Initiate Debt Restructuring}

The decision to initiate debt restructuring is made by the Arbitration Court.

From the date of the court decision to introduce a debt restructuring plan being taken the following consequences occur (Article 213.11 of the Bankruptcy Law):

- prohibition to satisfy financial claims of creditors. In other words, a moratorium similar to that on satisfaction of creditors' claims within external management is imposed (Article 95 of the Bankruptcy Law);

- the due date for fulfilling monetary obligations arising prior to filing bankruptcy is determined as occurred;

- penalties or other financial sanctions are not charged and so are interest charges. Thus, the debt does not increase by the amount of penalties or other financial sanctions except current payments and obligations that occur after filing bankruptcy;

- halting foreclosure proceedings;

- the court dismisses lawsuits filed out of bankruptcy proceedings and not considered prior to the debt restructuring;
- loss of the debtor's authority to dispose of his assets and finances (for instance, contribute his property to the authorized capital or participate in the share capital of a legal entity, acquire shares (stock or equity), make gratuitous transactions, sign some contracts on his own, open or close bank accounts etc.).

There are restrictions on contributing the debtor's property to the authorized capital or share capital of a legal entity, acquiring shares (stock or equity), making gratuitous transactions, signing some contracts on his own, opening or closing bank accounts or performing other meaningful legal acts.

Thus, during the debt restructuring procedure the debtor can make the following transactions only from written consent of the financial manager:

- acquire or deprive property worth more than 50000 rubles as well as any real estate, securities, shares in the authorized capital or vehicles;

- receive or give loans (credits), issue guarantee or surety bonds;

- assign the right to claim, transfer a debt and establish a trust;

- pledge property.

Other consequences occurring after initiating debt restructuring are listed in Article 213.11 of the Bankruptcy Law.

In case of disagreement between the debtor and financial manager regarding the abovementioned transactions, they are to be considered by the Arbitration Court (Par. 5 Cl. 5 Art. 213.11 of the Bankruptcy Law).

Transactions made without consent of the financial manager may be declared illegal at the request of the financial manager, bankruptcy creditor or authorized body (Cl. 1 Art. 173.1 of the Civil Code of the Russian Federation, Cl. 37 of Resolution № 45).

Apart from that, Article 14.13 of the Code of Administrative Offences of the Russian Federation $^{1}$ imposes an administrative penalty in the form of fine from 4000 to 5000 rubles in case of

\footnotetext{
${ }^{1}$ «The Code of Administrative Offences of the Russian Federation» of 30.12.2001 No. 195-FZ (as revised 06.07.2016) (amendments entered into force 03.10.2016) // Legislation Bulletin of the Russian Federation from 07.01.2002. No. 1(Part I) Art. 1.
} 
making a large purchase or selling a piece of property by the debtor without consent of the financial manager.

\section{Publication of Information about Validity of the Bankruptcy Petition and Debt Restructuring Initiation}

The second stage of the debt restructuring procedure is publication of information about the validity of the bankruptcy petition and debt restructuring initiation.

After the court decision to initiate debt restructuring is taken, the financial manager publishes a notice of the validity of the debtor's bankruptcy petition and restructuring his debts.

The notice is published in the Unified Federal Register of Bankruptcy Data and Kommersant newspaper, a specialized gazette for obligatory publication of the information on the progress of bankruptcy proceedings in accordance with the Bankruptcy Law (Article 213.7 of the Bankruptcy Law, Decree of the Government of the Russian Federation № 1049-r of July 21, 2008 “On the authorized source for publishing information on bankruptcies in accordance with the Federal Law "On Insolvency (bankruptcy)"1).

Creditors and other interested third parties are considered to be informed about the bankruptcy after the expiration of five working days since the publication of bankruptcy data in EFRSB.

The rules of the publication of bankruptcy data in EFRSB are set by the Order of the Ministry of Economic development of Russia of April 05, 2013 № 178 "On approval of the rules of formation and maintenance of the Unified Federal Register of data about the facts of activities of legal entities and the Unified Federal Register of bankruptcy data and the List of data liable for being included into the Unified Federal Register of bankruptcy data" ${ }^{2}$.

\footnotetext{
${ }^{1}$ On the Authorized Source for Publishing Information on Bankruptcies in Accordance with the Federal Law "On Insolvency (Bankruptcy): Decree of the Government of the Russian Federation of 21.07.2008 No. 049-r // Legislation Bulletin of the Russian Federation of 28.07.2008. No. 30 (Part II) Art. 3674.

${ }^{2}$ On Approval of the Rules of Formation and Maintenance of the Unified Federal Register of Data about the Facts of the Activities of Legal Entities and the Unified Federal Register of Bankruptcy Data and the List of Data Subject to Including in the Unified Federal Register of Bankruptcy Data: Order of the Ministry of Economic
}

The information about bankruptcy proceedings is published at the expense of the debtor.

\section{Sending Notifications of the Initiation of Debt Restructuring}

The financial manager sends notifications of the initiation of debt restructuring to all known creditors. It is not the right but the duty of the financial manager. The notifications ought to be sent not later than 15 days after the date when the court determines the bankruptcy petition and debt restructuring initiation to be valid.

In accordance with Clause 3 of Article 213.8 of the Bankruptcy Law, in the notification of bankruptcy the financial manager suggests that creditors should file their claims in the bankruptcy proceeding against the citizen and explains the procedure of filing.

\section{Filing creditors' claims to the debtor}

Filing creditors' claims to the debtor is the fourth stage of the procedure.

Clause 1 of Resolution № 45 clarifies that creditors' claims filed prior to October 1, 2015 are also considered upon the initiation of bankruptcy proceedings.

Creditors' claims are considered by the Arbitration Court in accordance with Article 71 and Article 100 of the Bankruptcy Law.

Claims filed by creditors and approved by the Arbitration Court are added to the Claims Register by the financial manager, and the creditors acquire the right to participate in the creditors' meetings proportional to the sum of their claims.

Creditor can file their claims during two months after the date of the publication of information about the debt restructuring initiation (Cl. 2 Art. 213.8, Cl. 4 Art. 213.24 of the Bankruptcy Law).

It is noticeable that, unlike bankruptcy of legal entities, in a citizen bankruptcy proceeding courts are permitted to restore the expired term for filing a claim in case of the valid reason for missing the filing deadline (Cl. 4 Art. 213.8, Cl. 4 Art. 213.24 of the Bankruptcy Law).

In their turn, the debtor has the right to object to the creditors' claims (Cl. 2 Art. 47, Cl. 6 Art. 213.5 of the Bankruptcy Law). In order to prevent abuse of law on the part of the debtor, the court is entitled to reject the debtor's objections aimed at delaying the bankruptcy procedure.

Development of Russia of 05.04.2013 No. 178 // Russian Gazette, No. 172, 07.08.2013. 
For instance, in the case if the debtor acknowledges the debt and delay in payment but objects to the initiation of the bankruptcy proceeding $(\mathrm{Cl} .14$ of Resolution № 45).

The creditors who filed their claims to the debtor also have the right to object to other creditors' claims in court (Cl. 2 Art. 71, Par. 2 Cl. 2 Art. 213.8 of the Bankruptcy Law). Such objections can be made during 15 days after the deadline for filing creditors' claims. It becomes particularly relevant when the debtor attempts to add an artificially created debt to the Claims Register in order to influence future decisions of the creditors' meetings.

It should be noted that the earlier and more timely the creditor files his claims, the more options there are for a debtor to determine his fate. For instance, taking part in the first creditors' meeting allows the debtor to express his position when it comes to making major decisions such as approving the debt restructuring plan or selling off the debtor's property.

\section{Drafting a Debt Restructuring Plan and Sending the Draft to the Interested Parties}

Drafting a debt restructuring plan and sending the draft to the interested parties is thought to be one of the most important stages of the procedure.

In accordance with Article 213.14 of the Bankruptcy Law, the plan should contain the terms and order of proportional repayment of the creditors' claims and interest on creditors' claims as well as the amount of monthly payments to the creditors.

The debtor, his creditors and the authorized body have the right to draft the debt restructuring plan and send the prepared drafts to the financial manager, all known creditors, the authorized body and the debtor (Art. 213.12 of the Bankruptcy Law).

In accordance with Clause 27 of Resolution № 45, the debt restructuring plan sent by the creditors or the authorized body should be accompanied by the debtor's written confirmation of the plan or objection to it.

The draft plan should be sent no later than during 10 days after the deadline for filing a creditor claim.

However, in accordance with Clause 28 of Resolution № 45 missing the deadline of sending the draft plan shall not be a ground for refusal to consider it at the first meeting of creditors on the condition that the draft plan arrived before the date of the meeting and the interested persons had enough time to read it and suggest their improvements or objections.

In accordance with the Bankruptcy Law, a debt restructuring plan can only be formulated for debt of a citizen who has at least one income source.

Furthermore, according to Clause 1 of Article 213.13 of the Bankruptcy Law the citizen should not have:

- unexpunged or outstanding conviction for the commission of a deliberate economic crime;

- administrative punishment for petty theft, deliberate damage or destruction of another person's property;

- unexpired term of fake or deliberate bankruptcy;

- recognition of bankruptcy during five years prior to the introduction of the debt restructuring plan;

- a debt restructuring plan approved within the last 8 years prior to the current plan.

In case of the occurrence of one of these circumstances, the citizen is recognized as a bankrupt without termination of the debt restructuring plan.

In addition, the citizen being a bankrupt is required by the Bankruptcy Law to inform the creditors about:

- the facts of administrative punishments for petty thefts, deliberate destruction or damage of another person's property, illegal actions, fake or deliberate bankruptcy;

- all known criminal or administrative proceedings against him as well as unexpunged or outstanding conviction;

- decisions to recognize the citizen as a bankrupt or restructuring of his debts terminated within the last eight years prior to the introduction of the current debt restructuring plan.

The abovementioned circumstances are included into the debt restructuring plan according to Clause 2 of Article 213.13 of the Bankruptcy Law.

\section{Approval of the debt restructuring plan}

The next stage of the procedure is approval of the debt restructuring plan at the meeting of creditors. 
In accordance with Clause 5 of Article 213.12 of the Bankruptcy Law, the financial manager has the duty to hold the first meeting of creditors no sooner than 20 days after the draft debt restructuring plan was sent to the creditors but no later than during 60 days after the deadline for filing creditors' claims.

In order to fulfill this duty, the financial manager sends a notification of the meeting to the creditors and the authorized body. The notification is to be included into EFRSB no later than 14 days prior to the meeting of creditors (Cl. 5 Art. 213.8 of the Bankruptcy Law).

The meeting of creditors is held according to the rules of Article 213.8 of the Bankruptcy Law.

A citizen's debt restructuring plan has to be approved by a simple majority from the total number of votes of creditors and authorized bodies included in the Claims Register (Art. 213.16 of the Bankruptcy Law). In case of disapproval of the plan, the court has the right to provide extra time to improve it after a petition by an interested party; however, the time should not exceed two months.

The debtor or his representative has the right to participate without vote in the first meeting of creditors. In the absence of the debtor at the first meeting of creditors, the meeting is neither canceled nor postponed (Cl. 1 Art. 213.8 of the Bankruptcy Law).

In case of the absence of the draft debt restructuring plan, the financial manager suggests the meeting of creditors recognizing the citizen as a bankrupt and selling his assets (Cl. 4 Art. 213.12 of the Bankruptcy Law).

In case the meeting of creditors approves of the suggested debt restructuring plan, the court has the right to make one of the following decisions $(\mathrm{Cl} .3$ Art. 21.17 of the Bankruptcy Law):

- to approve the plan;

- to postpone the matter;

- to refuse to approve the plan, declare the debtor bankrupt and initiate the sale of his assets.

The Arbitration Court can approve of the debt restructuring plan only after the citizen has satisfied current liabilities and has repaid debts to the creditors of the first and second priority whose claims are included in the Claims Register.

At the same time, the approval of the plan by the meeting of creditors is a sufficient ground for the court to adopt it, which means that no separate petition is required for this (Cl. 29 of Resolution № 45).

In case of the disapproval of the debt restructuring plan by the debtor, the Arbitration Court has the right to adopt the plan if the debtor is proved to abuse the process (Art. 10 of the Civil Code of the Russian Federation ${ }^{1}$ ). For instance, a citizen owning assets and stable high income insists on the quickest termination of the bankruptcy proceedings and debt relief (Cl. 30 of Resolution № 45).

The adoption of the debt restructuring plan by the Arbitration Court entails circumstances listed in Article 213.19 of the Bankruptcy Law.

The debt restructuring plan is provided for no more than three years from the date of its approval by the court. During this period, the debtor has to repay his debts to the creditors in accordance with the order and terms of the plan.

In addition, Clause 3 of Article 213.19 of the Bankruptcy Law includes a special circumstance for the debtor. The debtor has no right to hide execution of the debt restructuring plan in case of getting a loan or installment buying during the whole term of the plan and five years after its termination.

\section{Preparing the Financial Manager's Report and Termination of Debt Restructuring}

The last stage of the debt restructuring procedure is preparing the financial manager's report and termination of debt restructuring.

No later than a month before the end of the term of the debt restructuring plan, the financial manager prepares a report on execution of the plan by the debtor and sends it to the creditors, the authorized body and the court. The report is accompanied by the attached copies of the documents confirming satisfaction of the creditors' claims (Art. 213.22 of the Bankruptcy Law).

After receiving the report, the meeting of creditors have the right to file a petition to cancel the plan and declare the debtor bankrupt in case the debtor failed to satisfy the claims included in the plan or the financial manager did not present the report in due time.

\footnotetext{
${ }^{1}$ The Civil Code of the Russian Federation (Part I) of 30.11.1994 No. 51-FZ (as revised 03.07.2016) // Legal Bulletin of the RF. 05.12.1994, No. 32, Art. 3301.
} 
The Arbitration Court in its turn has the right to terminate the debt restructuring (if the debt is repaid in accordance with the plan and the creditors' complaints are invalid) or cancel the plan and declare the citizen bankrupt.

It is important to remember that the rules of debt restructuring are also applied in case of the bankruptcy of individual entrepreneurs (Art. 214.1 of the Bankruptcy Law) with the account of the rules specified in Clause 2 of Article X and Clause 4 of Article 213.1 of the Bankruptcy Law no matter whether the debt arose in connection with their entrepreneurial activities or not (Cl. 2 of Resolution № 45).

However, it is not possible to file two bankruptcy cases against a debtor being an individual entrepreneur - one as a natural person and the other as an individual entrepreneur. The court has to consider bankruptcy of such a person in a single case (Par. 3 Cl. 2 of Resolution № 45).

\section{Conclusions}

Legal consequences of debt restructuring (moratorium on meeting creditors' claims, fixed amount of debt, making certain transactions only with written consent of the financial manager etc.) allow for stabilizing the financial position of the debtor and keeping his property in order to satisfy creditors' claims. The actions of the financial manager are primarily aimed at fulfilling the creditors' rights to participate in the bankruptcy proceedings against the debtor. In their turn, creditors ought to be careful and cautious in order to keep their right to influence the legal fate of the debtor. The law additionally secures the creditors' claims of the first and second priority as well as current liabilities to creditors that ought to be paid before the debt restructuring plan confirmation.

Having considered some specific features of debt restructuring, it is possible to conclude that the legislation provides the debtor with a legal opportunity to repay debts over a long period of time due to moratorium on the satisfaction of creditors' claims and keeping the property.

Providing consumer debtors with different bankruptcy options depending on their obligations, income and debt amount, the legislation aims to protect the debtor from loss of property and psy- chological distress and thus to strengthen the socioeconomic infrastructure.

\section{References}

1. Zhukova T. M., Kondrat'eva K.S. Sudebnye meropriyatiya po vosstanovleniyu platezhesposobnosti grazhdan $v$ Rossii i za rubezhom [Judicial Actions for Restoration of Solvency of Citizens in Russia and Abroad]. Vestnik Permskogo universiteta. Yuridicheskie nauki Perm University Herald. Juridical Sciences. 2013. Issue 4(22). Pp. 162-169. (In Russ.).

2. Balz M. Insolvenzverfahren fur Verbraucher? Ztschr. Fur Rechtspolitik. Frankfurt a.M. 1986. Jg. 19. H. 1. Pp. 12-20. (In Ger.).

3. Boshkoff D. G. Fresh Start, False Start, or Heard Start? Indiana Law Journal. Bloomington. 1995. Vol. 70, №2. Pp. 549-568. (In Ger.).

4. Markell B.A. Bankruptcy, Lenity, and the Statutory Interpretation of Cognate Civil and Criminal Statutes. Indiana Law Journal. Bloomington. 1994. Vol. 69, № 2. Pp. 335-374. (In Eng.).

5. Warren E. Hearing on Bankruptcy Code and Individual Debtors. The Bankruptcy Code and Individual Debtors. Wash. 1992. Pp. 63-77. (In Eng.).

\section{References in Russian}

1. Жукова Т. М., Кондратьева К. С. Судебные мероприятия по восстановлению платежеспособности граждан в России и за рубежом // Вестник Пермского университета. Юридические науки. 2013. Вып. 4. С. 162-169.

2. Balz M. Insolvenzverfahren für Verbraucher? // Ztschr. Für Rechtspolitik. Frankfurt a. M., 1986. Jg. 19. H. 1. S. 12-20.

3. Boshkoff D.G. Fresh Start, False Start, or Heard Start? // Indiana Law Journal. Bloomington. 1995. Vol. 70, № 2. Pp. 549-568.

4. Markell B. A. Bankruptcy, lenity, and the statutory interpretation of cognate civil and criminal statutes // Indiana Law Journal. Bloomington, 1994. Vol. 69, № 2. Pp. 335-374.

6. Warren E. Hearing on Bankruptcy Code and individual debtors // The Bankruptcy Code and individual debtors. Wash, 1992. Pp. 63-77. 